\title{
Effect of salt stress on the parasitism of Meloidogyne enterolobii in cowpea
}

\author{
Efeito do stress salino sobre o parasitismo de Meloidogyne enterolobii em feijão-caupi Interacción \\ Efecto del estrés salino sobre el parasitismo de Meloidogyne enterolobii en el caupí
}

Received: 08/02/2021 | Reviewed: 08/06/2021 | Accept: 08/09/2021 | Published: 08/13/2021

\author{
Pedro Rodrigues Magalhães \\ ORCID: https://orcid.org/0000-0003-3408-8111 \\ Universidade Federal do Ceará, Brasil \\ E-mail: pedroagronomiaufc@gmail.com \\ Francisco Bruno da Silva Café \\ ORCID: https://orcid.org/0000-0001-8730-2666 \\ Universidade Federal do Ceará, Brasil \\ E-mail: bruno.cafe@ outlook.com \\ Francisco Jorge Carlos de Souza Junior \\ ORCID: https://orcid.org/0000-0003-2086-9857 \\ Universidade Federal Rural de Pernambuco, Brasil \\ E-mail: jorgesouza@alu.ufc.br \\ Rosilene Oliveira Mesquita \\ ORCID: https://orcid.org/0000-0002-6310-8196 \\ Universidade Federal do Ceará, Brasil \\ E-mail:rosilenemesquita@gmail.com \\ Carmem Dolores Gonzaga Santos \\ ORCID: https://orcid.org/0000-0002-3364-7623 \\ Universidade Federal do Ceará, Brasil \\ E-mail: carmelo.ufc@gmail.com
}

\begin{abstract}
Cowpea, Vigna unguiculata (L.) Walp, is a very important Fabaceae in the diet of families in the northeast region of Brazil. This plant species is among the different cultures affected by the root-knot nematode. In this region, in addition to phytonematodes, another condition that affects cowpea productivity is salinity, one of the main abiotic limiting factors. The cultivar Pitiúba, however, has good adaptability to salt stress conditions. However, information on the behavior of root-knot nematodes in an environment with high levels of salinity for this crop is still scarce. Based on the above, the objective of this work was: 1) to evaluate the hatchability of $\mathrm{J} 2$ of Meloidogyne enterolobii in $100 \mathrm{mM}$ $\mathrm{NaCl}$ solution; 2) evaluate the motility and infectivity of $\mathrm{J} 2$ of $M$. enterolobii in saline solution at the levels of 0,25 , $50,75,100,125,150,175,200,300$, and $400 \mathrm{mM}$; 3) to investigate the impairment of the development of $M$. enterolobii in cowpea Pitiúba under irrigation with $\mathrm{NaCl}$ solution at $100 \mathrm{mM}$. It was found that $\mathrm{J} 2$ hatching, motility, and infectivity of juveniles of $M$. enterolobii were not affected by the levels of salinity tested in vitro. In Pitiúba, irrigation with $100 \mathrm{mM}$ saline solution considerably affected the development of juveniles of the pathogen in the roots.
\end{abstract}

Keywords: Root-knot nematodes; Vigna unguiculata; Salinity.

\section{Resumo}

O feijão-caupi, Vigna unguiculata (L.) Walp, é uma fabácea muito importante na dieta de famílias da região nordeste do Brasil. Esta espécie de planta está entre as diferentes culturas afetadas pelo nematoide das galhas. Nessa região, além dos fitonematóides, outra condição que afeta a produtividade do feijão-caupi é a salinidade, um dos principais fatores limitantes abióticos. A cultivar Pitiúba, entretanto, apresenta boa adaptabilidade às condições de estresse salino. No entanto, informações sobre o comportamento dos nematoides das galhas em ambiente com altos níveis de salinidade para esta cultura ainda são escassas. Com base no exposto, o objetivo deste trabalho foi: 1) avaliar a eclodibilidade de $\mathrm{J} 2$ de Meloidogyne enterolobii em solução de $\mathrm{NaCl} 100 \mathrm{mM}$; 2) avaliar a motilidade e infectividade de J2 de M. enterolobii em solução salina nos níveis de 0, 25, 50, 75, 100, 125, 150, 175, 200, 300 e 400mM; 3) investigar o comprometimento do desenvolvimento de $M$. enterolobii em feijão-caupi Pitiúba sob irrigação com solução de $\mathrm{NaCl}$ a $100 \mathrm{mM}$. Verificou-se que a eclosão de $\mathrm{J} 2$, a motilidade e a infectividade dos juvenis de $M$. enterolobii não foram afetadas pelos níveis de salinidade testados in vitro. Em Pitiúba, a irrigação com solução salina $100 \mathrm{mM}$ afetou consideravelmente o desenvolvimento de juvenis do patógeno nas raízes.

Palavras-chave: Nematoides das galhas; Vigna unguiculata; Salinidade. 


\section{Resumen}

El caupí, Vigna unguiculata (L.) Walp, es una fabaceae muy importante en la dieta de las familias de la región noreste de Brasil. Esta especie vegetal se encuentra entre los diferentes cultivos afectados por el nematodo agallador. En esta región, además de los fitonematodos, otra condición que afecta la productividad del caupí es la salinidad, uno de los principales factores limitantes abióticos. El cultivar Pitiúba, sin embargo, tiene una buena adaptabilidad a las condiciones de estrés salino. Sin embargo, la información sobre el comportamiento de los nematodos agalladores en un ambiente con altos niveles de salinidad para este cultivo es aún escasa. Con base en lo anterior, el objetivo de este trabajo fue: 1) evaluar la incubabilidad de J2 de Meloidogyne enterolobii en solución de $\mathrm{NaCl} 100 \mathrm{mM}$; 2) evaluar la motilidad e infectividad de $\mathrm{J} 2$ de $M$. enterolobii en solución salina a niveles de 0, 25, 50, 75, 100, 125, 150, 175, 200, 300 y 400 mM; 3) investigar el deterioro del desarrollo de M. enterolobii en caupí Pitiúba bajo riego con solución de $\mathrm{NaCl}$ a $100 \mathrm{mM}$. Se encontró que la eclosión de J2, la motilidad y la infectividad de los juveniles de M. enterolobii no se vieron afectadas por los niveles de salinidad probados in vitro. En Pitiúba, el riego con solución salina $100 \mathrm{mM}$ afectó considerablemente el desarrollo de juveniles del patógeno en las raíces.

Palabras clave: Nematodos Agalladores; Vigna unguiculata; Salinidad.

\section{Introduction}

Salinity is a limiting factor for plant development, due to decreased productivity in several agronomic crops decreasing the rate of absorption by the root system, with changes in the assimilation and transport of water and nutrients in the plant, producing disturbances at the physiological and physical level in plants (Sá et al., 2018; Souza et al., 2019). Soil salinity is a worldwide problem that affects approximately $10 \%$ of all soils and half of the irrigated areas in the world (Kamran et al., 2020; Singh, 2021). Salinization is a process that occurs in poorly managed soils, usually with poor drainage conditions, indiscriminate use of fertilizers, low-quality water used for irrigation, or natural causes due to the weathering of rocks, which have high levels of soluble salts (Aderaldo et al., 2020; Araújo et al., 2019). A soil is considered saline when it has an electrical conductivity greater than $4 \mathrm{dS} / \mathrm{m}(40 \mathrm{mM})$ (Jesus \& Borges, 2020). The high concentration of salts in the soil solution occurs mainly in arid and semi-arid regions in the world (Oliveira et al., 2015; Etikala et al., 2021).

In Brazil, in the northeast region, the occurrence of salinity problems in soils is commonly reported, mainly due to the use of low-quality water, with the accumulation of $\mathrm{Na}^{+}$and $\mathrm{Cl}^{-}$ions, in irrigation (Ribeiro et al., 2016; Vasconcelos et al., 2013).

Research aimed at improving plant species resistance to abiotic factors has been gaining more and more notoriety in the world. Among the plants with a tolerance to salinity, cowpea (Vigna unguiculata (L.) Walp) is an example, a species well adapted to the edaphoclimatic conditions of the northeast region of Brazil (Ayers \& Westcot, 1999; Silva et al., 2020).

In addition to salinity, diseases caused by phytonematodes are also an important problem for cultures worldwide, highlighting the species of the genus Meloidogyne Goeldi. In Brazil, among the several species of root-knot nematode that have already been identified in the northeast region, there is the highlight for M. enterolobii Yang and Eisenback, commonly associated with the losses caused in the guava tree (Psidium guajava L.) (Castro, 2019; Cavalcanti et al., 2021). In addition to this fruit, this pathogen has a wide range of hosts, including grain-producing crops, such as cowpea (Castro, 2019; Guimarães et al., 2003), already registered Fabaceae associated with Meloidogyne spp. in the northeast region (Sobrinho, 2016). In Ceará state, isolates of M. enterolobii were recorded in several agricultural regions in different cultures (Silva et al., 2017). The rootknot nematodes can adapt to various environments with variations in temperature, humidity, and salinity (Adrian et al., 2009).

In the literature, there are several studies on the effects of salinity on the physical and chemical properties of the soil (Sardinha et al., 2003), but few studies focusing on soil microbiota. Information on the behavior of root-knot nematodes in an environment with salinity levels is also scarce.

Thus, the objectives of this work were: i. evaluate the hatching of juvenile of the second stage (J2) of M. enterolobii in saline solution at $100 \mathrm{mM} \mathrm{NaCl}$; ii. evaluate the motility and survival of $\mathrm{J} 2$ of $\mathrm{M}$. enterolobii in saline solution at different levels of salinity; iii. to investigate the infectivity and the development of $M$. enterolobii in cowpea under irrigation with saline 
solution at the level of $100 \mathrm{mM} \mathrm{NaCl}$.

\section{Methodology}

To evaluate the interaction between saline stress and $M$. enterolobii parasitism in cowpea, the cultivar Pitiúba launched by Federal University of Ceará (UFC) was selected, which stands out for its good agronomic characteristics and for having good adaptability to salt stress conditions (Paiva et al., 2014).

The population of $M$. enterolobii used in this study came from the collection of phytonematodes from the Phytopathology Laboratory of UFC, whose identification of the isolate was carried out by molecular techniques (Silva et al., 2016). The extraction of eggs from the roots for the tests was carried out according to the methodology of Bonetti \& Ferraz (1981). The choice of this Meloidogyne species was related to its occurrence in several microregions in Ceará state (Silva et al., 2016).

To evaluate the in vitro effect of salinity on the hatching of juveniles of $M$. enterolobii, 50 eggs of the phytonematode were added in $3 \mathrm{~mL}$ of a solution with $100 \mathrm{mM} \mathrm{NaCl}$, distributed in Petri dishes of $3 \mathrm{~cm}$ in diameter. Distilled water was used as a control. The plates were placed in trays and kept in the environment, at approximately $27^{\circ} \mathrm{C}$. The hatching of the $\mathrm{J} 2 \mathrm{~s}$ was evaluated daily for 15 days after the assembly of the bioassay. The design used was completely randomized, consisting of 2 treatments and 6 repetitions, in which each plate composed one repetition, totaling 12 plates and 600 eggs.

For the in vitro study of motility, survival, and infectivity of $M$. enterolobii in phase $\mathrm{J} 2$ in saline solution, juveniles obtained from egg masses taken from Santa Clara tomato roots (Solanum lycopersicum L.) were used in a hatching chamber. The bioassay was divided into two stages. The first phase consisted of depositing 50 individuals of $\mathrm{J} 2$ of $M$. enterolobii in saline solution in Petri dishes of $3 \mathrm{~cm}$ in diameter, in different salt concentrations $(0,25,50,75,100,125,150$, $175,200,300$, and $400 \mathrm{mM} \mathrm{NaCl}$ ). After the 48 -hour incubation period at $27^{\circ} \mathrm{C}$, mobile and immobile juveniles were counted to determine survival and mortality. To confirm mortality, the immobile J2 were transferred from saline solutions to a Petri dish containing distilled water, and after 24 hours the individuals were again evaluated. This bioassay was conducted in a completely randomized design, consisting of 11 treatments with 6 replications, totaling 66 plates and 3,300 juveniles.

Considering that the Pitiúba cowpea, a variety selected for use in the other trials, supports salinity well at the maximum level of 100mM NaCl (Alves, 2015), it was decided to test the infectivity of juveniles submitted to this level of salinity, extending the individuals remained in the $100 \mathrm{mM}$ saline solution for 15 days, during which time they still had motility. Thus, 150 individuals were removed directly from the saline solution and inoculated in Santa Clara tomato seedling, after 45 days, to evaluate the presence, or not, of root-knots on the roots. Juveniles that remained in the water for 15 days were also inoculated in another tomato seedling. In both cases, the tomatoes kept in the greenhouse were irrigated with water.

The cowpea seeds, cultivar Pitiúba, were obtained from the UFC Germplasm Bank. A cowpea seed was planted per pot with a capacity of $1.5 \mathrm{~L}$, containing river sand washed 5 times, to remove salts and clays present, and autoclaved at $120{ }^{\circ} \mathrm{C}$ for 50 min. From 10 days after sowing, the plants were subjected to irrigation with saline or desalinated water. At 12 DAS, 5,000 eggs/J2 of M. enterolobii were inoculated, according to the following treatments: A. plants inoculated and irrigated with $100 \mathrm{mM} \mathrm{NaCl}$ solution; B. plants inoculated and irrigated with desalinated water; C. uninoculated plants, and irrigated with $100 \mathrm{mM} \mathrm{NaCl}$ solution; D. plants not inoculated and irrigated with desalinated water (control), which were examined in two periods, 15 and 18 days after inoculation. The trial was conducted in a completely randomized design, resulting in 4 treatments with 10 repetitions. The desalinated water used in this study was obtained through the WW2 desalinator (Ferran®). Irrigation was performed daily in each pot.

Part of the plants from the 4 treatments was removed at 15 DAI (17 days of irrigation with saline) and the rest of the 
plants after 18 DAI (20 days of irrigation with saline). The difference in the evaluation period was due to the chlorotic aspect presented by the plants, which was accentuated at 18 days, with the end of the bioassay. Considering the time elapsed from inoculation at the end of the test, the number of galls (NG) and the nematode development stages present in the roots at 15 and 18 DAI were considered for the evaluation. To identify the phases of the pathogen in the root system, the method of staining root nematodes with acid fuchsin was used (Byrd et al., 1983). The 1 to $2 \mathrm{~cm}$ sections of the stained roots were distributed in slides that were then pressed with a coverslip, for observation and recording of the nematode phases present under an optical microscope.

All bioassays were repeated twice. The quantitative data were subjected to analysis of variance (ANOVA) and the averages to the Tukey test at the level of 5\% probability, using the Sisvar software (Ferreira, 2014).

\section{Results and Discussion}

The data for the hatching of $M$. enterolobii from the control treatments (distilled water) and $100 \mathrm{mM} \mathrm{NaCl} \mathrm{solution}$ can be seen in Table 1.

Table 1. Hatching percentage of second stage juveniles of Meloidogyne enterolobii under interference of a $100 \mathrm{mM} \mathrm{NaCl}$ solution and desalted water (control) at 3, 6, 9 and 12 days.

\begin{tabular}{lllll}
\hline Treatments & $\mathbf{3}^{\mathbf{0}}$ Day & $\mathbf{6}^{\mathbf{0}}$ Day & $\mathbf{9}^{\mathbf{0}}$ Day & $\mathbf{1 2}^{\mathbf{0}}$ Day \\
\hline $100 \mathrm{mM}$ of $\mathrm{NaCl}$ & 12 & 32 & 94 & 100 \\
\hline Control & 6 & 28 & 86 & 100 \\
\hline
\end{tabular}

Source: Authors.

In the first evaluations $\left(3^{\circ}\right.$ and $6 \mathrm{t}^{\circ}$ day), the use of $\mathrm{NaCl}$ in the concentration of $100 \mathrm{mM}$ did not affect the hatching of juveniles of $M$. enterolobii, observing that from the 9th day the number of hatched $\mathrm{J} 2$ was similar to the control, occurring in both treatments $100 \%$ hatching on the $12^{\circ}$ day (Table 1 ).

Table 2 shows the results for the average number of immobile $\mathrm{J} 2$ after immersion in various concentrations of $\mathrm{NaCl}$ solution (0-400 $\mathrm{mM})$ and the percentage of $\mathrm{J} 2$ that recovered motility after passing in distilled water.

Table 2. Data on the mean of second stage juveniles motility of $M$. enterolobii after $24 \mathrm{~h}$ and $48 \mathrm{~h}$ of immersion in saline in different concentrations of $\mathrm{NaCl}$.

\begin{tabular}{|c|c|c|c|}
\hline $\begin{array}{l}\text { Concentrations of } \\
\mathrm{NaCl}(\mathrm{mM})\end{array}$ & $\begin{array}{r}\text { J2 not mobile } \\
(24 h)\end{array}$ & $\begin{array}{r}\text { J2 not mobile } \\
(48 \mathrm{~h})\end{array}$ & $\begin{array}{r}\text { J2 mobile* } \\
(\%)\end{array}$ \\
\hline 0 & 0.0 & $0.0 \mathrm{f}$ & - \\
\hline 25 & 0.0 & $0.0 \mathrm{f}$ & - \\
\hline 50 & 0.0 & $0.0 \mathrm{f}$ & - \\
\hline 75 & 0.0 & $0.0 \mathrm{f}$ & - \\
\hline 100 & 0.0 & $2.2 \mathrm{ef}$ & 100 \\
\hline 125 & 0.0 & 3.7 ef & 100 \\
\hline 150 & 0.0 & $5.3 \mathrm{e}$ & 100 \\
\hline 175 & 0.0 & $13.5 \mathrm{~d}$ & 100 \\
\hline 200 & 0.0 & $24.7 \mathrm{c}$ & 100 \\
\hline 300 & 0.0 & $41.0 \mathrm{~b}$ & 100 \\
\hline 400 & 0.0 & $48.7 \mathrm{a}$ & 100 \\
\hline $\mathrm{CV}^{1}$ & - & 15.74 & - \\
\hline
\end{tabular}

*After $48 \mathrm{~h}$ in saline and $24 \mathrm{~h}$ in distilled water.

${ }^{1} \mathrm{CV}$ : coefficient of variation.

Source: Authors. 
As shown in Table 2, after $24 \mathrm{~h}$ of immersion in the 11 treatments, all $\mathrm{J} 2$ of $M$. enterolobii were perfectly active. However, after 48 hours, the occurrence of juvenile immotility was verified, which increased with the increase in salinity levels, being higher than $97 \%$ in $400 \mathrm{mM}$. In the control and at the levels of 25,50 , and $75 \mathrm{mM}$, immotility was not observed in the individuals even after $48 \mathrm{~h}$ of exposure in saline solution, the reason for which they were not transferred to the distilled water. All immovable $\mathrm{J} 2$ in solutions with concentrations between 100 and $400 \mathrm{mM} \mathrm{NaCl}$ recovered their movement after being transferred to distilled water (Table 2), indicating a nematostatic effect at concentrations above $100 \mathrm{mM}$.

In the second part of the trial, when investigating the infectivity of juveniles after 15 days in saline, it was found, after 45 days, the presence of many galls in the roots of inoculated Santa Clara tomato plants, both with juveniles that were exposed to salinity as with those who stayed in the water, thus demonstrating that J2 infectivity was not affected by salt (Fig. 1A-B).

Figure 1. Galls on Santa Clara tomato root 45 days after inoculation of Meloidogyne enterolobii with:

A. J2 that remained in saline solution for 15 days; B. J2 that remained in water (control).

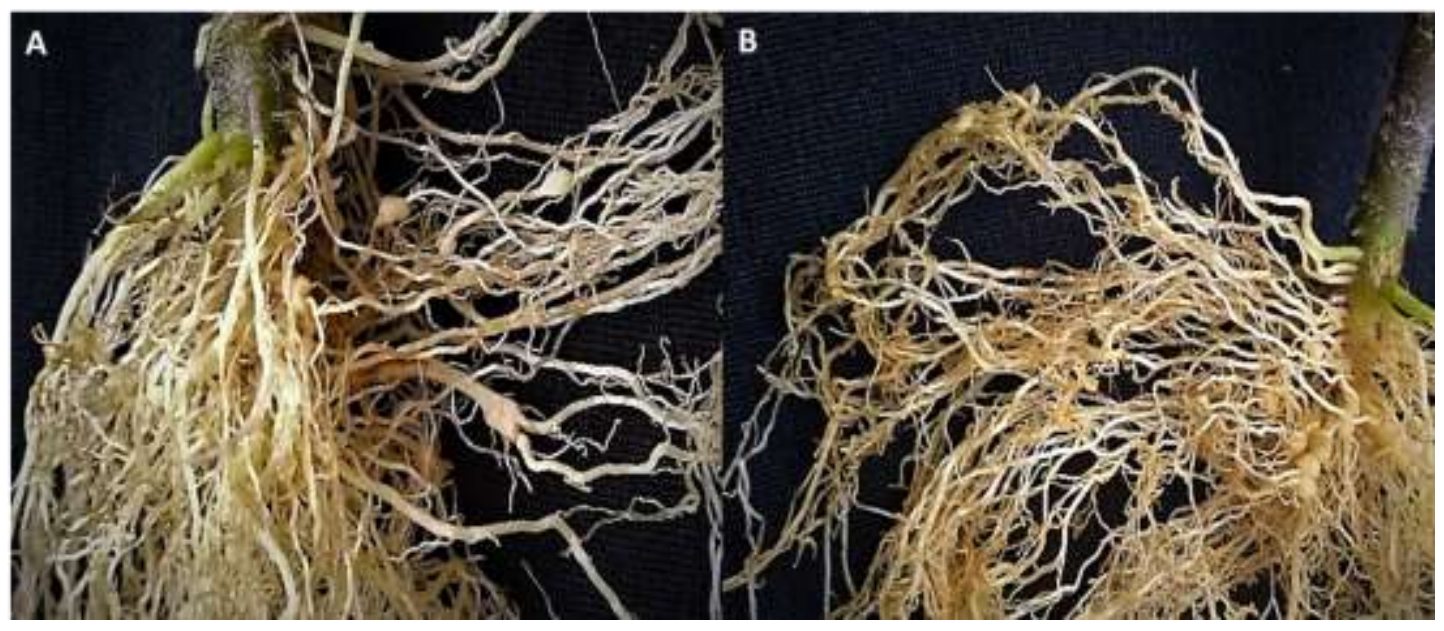

Source: Authors.

The examination using an optical microscope of the roots stained with acid fuchsin from Pitiúba plants irrigated with $100 \mathrm{mM}$ saline solution and with water showed different results regarding the number and development of nematode phases (Table 3).

Table 3. The average number of $M$. enterolobii individuals present in Pitiúba roots irrigated with $100 \mathrm{mM}$ saline solution for 15 and 18 days.

\begin{tabular}{lcccc}
\hline \multirow{2}{*}{ Stages } & \multicolumn{2}{c}{$\mathbf{1 5}^{\mathbf{0}} \mathbf{\text { DAI* }}$} & \multicolumn{2}{c}{$\mathbf{1 8}^{\mathbf{0}} \mathbf{D A I}^{*}$} \\
& Saline solution & Control & Saline solution & Control \\
\hline J2 & 24.7 & 17.3 & 4.3 & 19.2 \\
J3 & 0.0 & 42.6 & 0.6 & 68.4 \\
J4 & 0.0 & 40.0 & 2.1 & 82.2 \\
Female & 0.0 & 0.6 & 0.0 & 4.0 \\
\hline
\end{tabular}

*DAI: days after inoculation.

Source: Authors.

At $15^{\circ} \mathrm{DAI}$, the roots of plants irrigated with the saline solution presented average values of $24.7 \mathrm{~J} 2$, varying from 10 to 55 individuals/root (Fig. 2A). Phases J3 and J4 were not observed, nor the presence of galls on the roots. For plants irrigated 
with desalinated water, the average values were 17.3 (7-35) J2, while for J3 the average was 42.6 (11-98). The mean for J4 was $40(12-56)$ and for females $0.6(0-2)$ (Fig. 2B). In these plants, an average number of 14 galls was observed.

Figure 2. Meloidogyne enterolobii 15 days after inoculation in cowpea Pitiúba irrigated with: A) saline solution presenting only second stage juveniles; B) desalinated water with many third and fourth stage individuals.

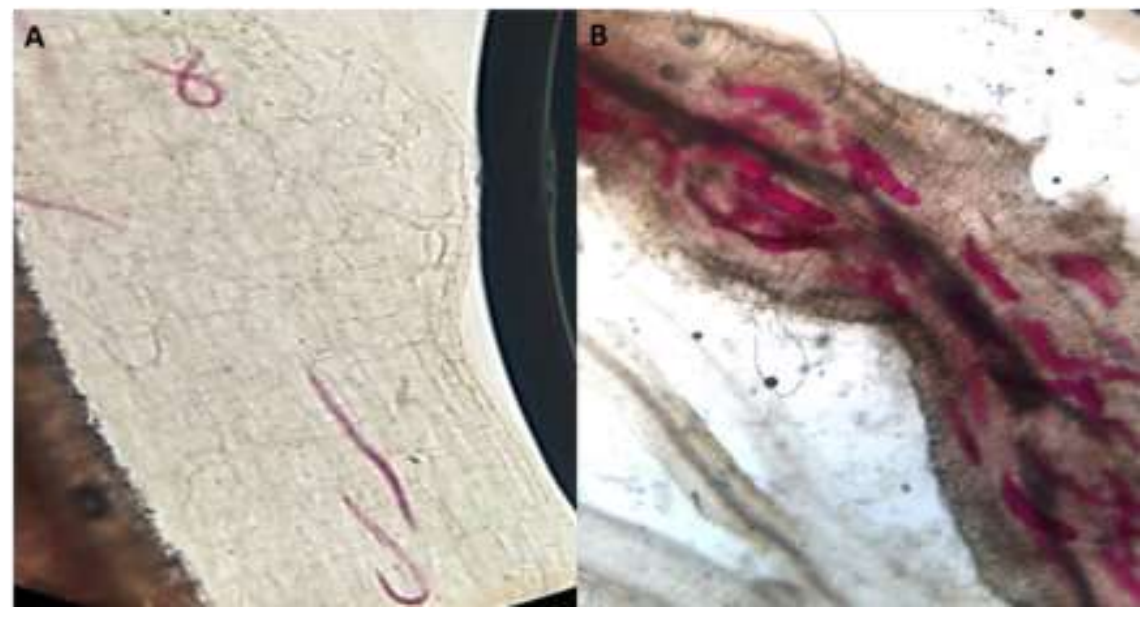

Source: Authors.

The plants removed at $18^{\circ} \mathrm{DAI}$, kept under irrigation with the saline solution presented average values of $4.3 \mathrm{~J} 2$ (112) (Figure 3A), $0.6 \mathrm{~J} 3$ (0-2), $2.1 \mathrm{~J} 4$ (3-10), and absence of females. Plants irrigated with desalinated water had an average value of $19.2 \mathrm{~J} 2$ (0-47), $68.4 \mathrm{~J} 3$ (31-89), $82.2 \mathrm{~J} 4$ (44-127), 4.0 females (1-9), and 35.4 galls (Fig. 3B).

Figure 3. Pitiúba cowpea roots 18 days after inoculation with Meloidogyne enterolobii presenting: A) only spindly and cylindrical second stage juveniles (saline); B) presence of females (desalinated water).

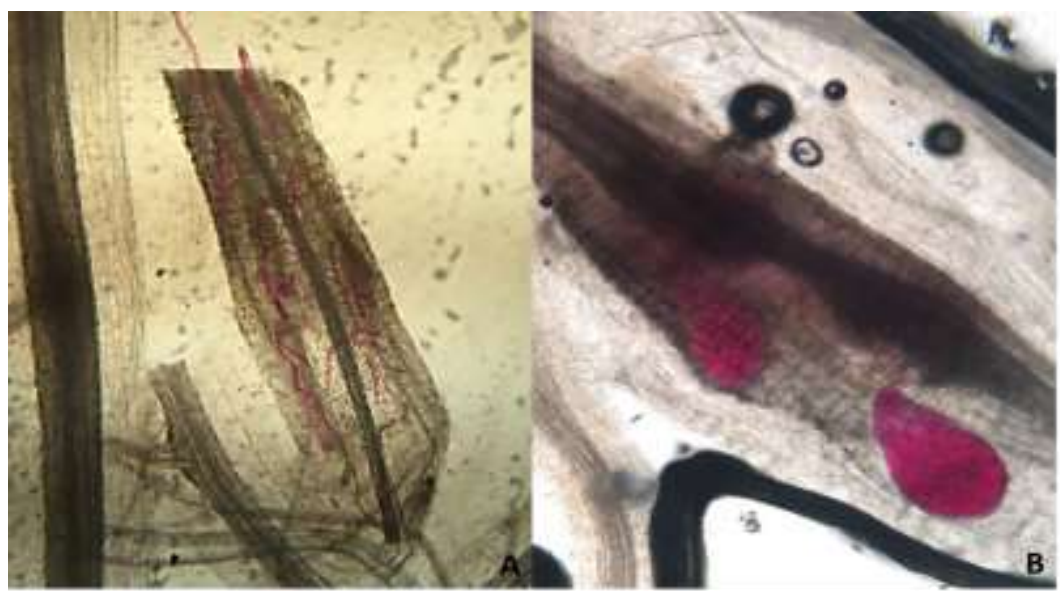

Source: Authors.

\section{Discussion}

In the present study, the hatching of M. enterolobii was not influenced by the concentration of $100 \mathrm{mM} \mathrm{NaCl}$ tested. This result differs from those observed in some works published with this genus of phytonematodes. It has been 
reported that the hatching of juveniles of Meloidogyne spp. it is affected by salinity, with a decrease in hatching rate as the salinity increases, as exemplified by Dropkin et al. (1958), Edongali \& Farris (1981), Khan \& Khan (1990), and Lal \& Yadav (1975). Adrian et al. (2009) revealed that the concentration of $300 \mathrm{mM} \mathrm{NaCl}$ can induce $\mathrm{J} 2$ quiescence of $M$. javanica and that M. hapla is intolerant to $800 \mathrm{mM} \mathrm{NaCl}$. Shepherd \& Clarke, 1971 found that the hatching of juvenile nematodes is influenced by different factors, such as temperature, soil moisture, $\mathrm{pH}$, and organic or inorganic chemical components present in the soil water solution. In general, there is a lack of research on the hatchability of Meloidogyne spp. in saline conditions in Brazil.

Regarding the infectivity of $\mathrm{J} 2$ in the presence of saline solution, similar results to this study were obtained by Edongali \& Ferris (1981) who observed that the infectivity of J2 de Meloidogyne spp. it was not altered after exposure to NaCl for seven days. According to the authors, the number of galls in tomatoes was higher than the control with water, possibly due to the osmoregulation process in $\mathrm{J} 2$.

Khan \& Khan (1990) observed that $\mathrm{NaCl}$ at a concentration of $5 \mathrm{mM}$ significantly induced the mortality of $\mathrm{J} 2$ from $M$. javanica and $M$. incognita. However, in this study, $\mathrm{J} 2$ of $M$. enterolobii was not affected in the $100 \mathrm{mM}$ saline solution even after 15 days.

The high permeability of nematodes to ions has a deleterious effect on their metabolism, and this unbalances several biological processes in phytonematodes, including infectivity as reported by Adrian et al. (2009) in M. incognita inoculated with $\mathrm{J} 2$ submitted to different concentrations of $\mathrm{NaCl}$ in tomato.

In general, a delay in the development of the $\mathrm{J} 2$ phase of $M$. enterolobii in plants irrigated with saline compared to the control was found in this test. Similar results were obtained by Heald \& Heilman (1971) for Rotylenchulus reniformis, who attributed the delay of $R$. reniformis juveniles to the limitation of the development of the root system of the cotton plant by salinity and not by the direct effect of salinity on nematodes. Corroborating this information, Sumera et al. (2015) in experiments involving salinity $(1.71 \mathrm{mM} \mathrm{NaCl})$, conducted with eggplant (Solanum melongena L.) inoculated with M. javanica, observed impairment in the development of juveniles, reporting a greater number of $\mathrm{J} 2$ and a lower number of $\mathrm{J} 3$ and J4 in eggplant roots when compared to the control with water.

Wallace (1966) mentions that the success of juvenile root infection depends on factors such as an adequate host and the speed of $\mathbf{J} 2$ penetration, with the osmotic potential and $\mathrm{pH}$ having less influence. Edongali et al. (1982), however, found that the penetration of $M$. incognita juveniles into tomato plants was affected by the concentration of saline in the soil, which may have caused the depletion of their body reserves, possibly leading to less infectivity by reducing metabolic activity and movement in the soil, which could inhibit the search for infection sites in the root. The authors also cite a delay in the formation of mature females in saline conditions, but that they may be able to produce eggs. Possibly, the difference in the number and phases of individuals of $M$. enterolobii observed in the roots irrigated with saline solution compared to water, in the two periods evaluated (15 and 18 days), where it was always observed in a greater number of individuals from phase $\mathrm{J} 2$, it could be attributed to a supposed delay in penetration coupled with depletion of their bodily reserves, resulting in a delay in the development of juveniles at the roots.

Khan et al. (1997) in trials with $M$. incognita race 2 in okra and cucumber mentioned that there was less penetration of juveniles and delayed development in plant roots in saline soils $(50 \mathrm{mM})$. The delay induced by salinity in pathogenicity and the production of females and egg mass can lead to a reduction in the population of the pathogen. According to the authors, the apparent suppression of salinity in the penetration and reproduction of the nematode results in some improvement for the growth of plants. 
In studies by Asif et al. (2021) and Devran \& Baysal (2018), who used the same NaCl concentration in this study (100 $\mathrm{mM}$ ) to irrigate tomato plants inoculated with $M$. incognita, a reduction in the number of galls was observed, a behavior similar to that verified in this research with $M$. enterolobii.

In contrast to this information, in a study conducted with plants whose citrus rootstocks, both sensitive and resistant to Tylenchulus semipenetrans Cobb, were exposed to salinity, Mashela et al. (1992) observed that there was a predisposition of plants to parasitism by the nematode. The accumulation of salt and the leaching cycles in the soil would have favored the increase of the population of the pathogen in the roots. According to the authors, similar behavior occurs during the rainy season in infested orchards irrigated with saline water during the dry season.

\section{Conclusion}

Salinity did not affect hatching and motility of $M$. enterolobii juveniles in vitro and the presence of $\mathrm{J} 2$ in saline solution for 15 days did not interfere with its infectivity in tomato. However, the irrigation with saline solution at $100 \mathrm{mM}$ $\mathrm{NaCl}$ in Pitiúba inoculated with $\mathrm{M}$. enterolobii considerably reduced the development of juveniles of the pathogen in tomato roots.

\section{Acknowledgments}

The authors would like to thank Coordenação de Aperfeiçoamento de Pessoal de Nível Superior (CAPES).

\section{References}

Aderaldo, F. Í. C., Braga, J. D. A. F., Ferreira, G. S., Costa, F. R. S., Brito, P. O. B. \& Gondim, F. A. (2020). Efeitos combinados da seca e da salinidade no crescimento de plantas de mulungu (Erythrina Velutina Wild). Brazilian Journal of Animal and Environmental Research, 3(3), $2732-2740$.

Adrian, A. F., Evans, A. A. F. \& Perry, R.N. (2009). Survival mechanisms. Editor(s): Perry, R.N., Moens, M. \& Starr, J. L., In Root-knot Nematodes. Cambridge: CABI International, Pages 201-222.

Alves, F. A. L., Silva, S. L. F., Maia, J. M., Freitas, J. B. S. \& Silveira, J. A. G. (2015). Regulação do acúmulo de Na ${ }^{+}$e resistência à salinidade em (Vigna unguiculata (L.) Walp). Pesquisa Agropecuária Pernambucana, 20(1), 1-10.

Araújo, B. D. A., Moreira, F. J. C., \& Guedes, F. L. (2019). Emergência e crescimento inicial de feijão guandu em função dos substratos e salinidade da água de irrigação. Revista Agrária Acadêmica, 2(4), 90-101.

Asif, M., Khan, F., Ansari, T., Ahmad, F., Tariq, M., Khan, A., Shariq, M. \& Siddiqui, M. A. (2021). dl- $\beta$-Amino butyric acid induced resistance in tomato against root-knot nematode Meloidogyne incognita under salt stress condition. Indian Phytopathology, 74(1), 1-4.

Ayers, R. S. \& Westcot, D. W. (1999). A qualidade da água na agricultura. Campina Grande: UFPB.

Bonetti, J.I.S. \& Ferraz, S. (1981). Modificações do método de Hussey \& Barker para extração de ovos de Meloidogyne exigua em raízes de cafeeiro. Fitopatologia Brasileira, 6 (3), 553.

Byrd, D.W. J., Kirkpatrick, J. \& Barker, K. R. (1983). An improved technique for clearing andstaining plant tissues for detection of nematodes. Journal of Nematology, 15(1), 142-143.

Castro, J. M. C. (2019). Meloidogyne enterolobii e sua evolução nos cultivos brasileiros. Informe Agropecuário, 40 (306), 41-48.

Cavalcanti, E. D. A., Moraes, R. M. D., Rossiter, J. G. D. A., Montarroyos, A. V. V., Musser, R. D. S. \& Martins, L. S. S. (2021). Reação de genótipos do gênero Psidium spp. a Meloidogyne enterolobii. Summa Phytopathologica, 46, 333-339.

Devran, Z. \& Baysal, Ö. (2018). Induction of resistance to Meloidogyne incognita by DL-Beta amino butyric acid under salt stress condition. Australasian Plant Disease Notes, 13(1), 1-3.

Dropkin, V.H., Martin, G.C. \& Johnson, R.W. (1958). Effect of osmotic concentration on hatching of some plant parasitic nematodes. Nematologica, 3, 115126.

Edongali, E. A. \& Farris, H. (1981). Effect of salinity and temperature on reproduction and egg hatching of Meliodogyne incognita in tomato. Nematologia Mediterranea, 9, 123-132

Edongali, E.A., Duncan, L. \& Ferris, H. (1982). Influence of salt concentration on infectivity and development of Meliodogyne incognita on tomato. Review Nematology, 5(1), 111-117. 
Etikala, B., Adimalla, N., Madhav, S., Somagouni, S. G. \& Keshava Kiran Kumar, P. L. (2021). Salinity Problems in Groundwater and Management Strategies in Arid and Semi-arid Regions. In Madhav S. \& Singh P. Groundwater Geochemistry: Pollution and Remediation Methods, Nova Jersey: John Wiley \& Sons. Pages 42-56.

Guimarães, L. M., Moura, R. M. \& Pedrosa, E. M. R. (2003). Parasitismo de Meloidogyne mayaguensis em diferentes espécies botânicas. Nematologia Brasileira, 27(2), 139-145.

Heald, C.M. \& Hellman, M. D. (1971). Interaction of Rotylenchulus reniformis, soil salinity and cotton. Journal of Nematology, 3, $179-182$.

Jesus, J., \& Borges, M. T. (2020). Salinização de solos em Portugal. Revista de Ciência Elementar, 8(3), 1-5.

Kamran, M., Parveen, A., Ahmar, S., Malik, Z., Hussain, S., Chattha, M. S., Saleem, M. H., Adil, M., Heidari, P. \& Chen, J. T. (2020). An overview of hazardous impacts of soil salinity in crops, tolerance mechanisms, and amelioration through selenium supplementation. International Journal of Molecular Sciences, 21(1), 148.

Khan, A.A. \& Khan, M.W. (1990). Influence of salinity stresses on hatching and juvenile mortality of root-knot nematode, Meloidogyne incognita (race 2) and Meloidogyne javanica. Pakistan Journal of Nematology, 8, 107-111.

Khan, M. W., Khan, A. A. \& Khan, M. R. (1997). Effect of soil salinity on penetration, development and pathogenicity of Meloidogyne incognita on okra and cucumber. Indian Journal of Nematology, 27(2), 194-208.

Lal, A. \& Yadav, B. S. (1975). Effect of leachate from saline soils on hatching of eggs of Meloidogyne incognita. Indian Journal of Nematology, 5, 228-229.

Mashela, P., Duncan, L. \& Mcsorley, R. (1992). Salinity reduces resistance to Tylenchus semipenetrans in citros rootstocks. Nematropica, $22(1), 7-12$.

Oliveira, F. D. A. D., Medeiros, J. F. D., Alves, R. D. C., Lima, L. A., Santos, S. T. D. \& Régis, L. R. D. L. (2015). Produção de feijão caupi em função da salinidade e regulador de crescimento. Revista Brasileira de Engenharia Agrícola e Ambiental, 19 (11), $1049-1056$.

Paiva, J. B, Freire filho, F. R., Teófilo, E. M. \& Ribeiro, Q. V. (2014). Feijão-caupi: Melhoramento Genético no Centro de Ciências Agrárias. Fortaleza: Edições UFC.

Ribeiro, M. R., Ribeiro Filho, M. R. \& Jacomine, P. K. T. (2016). Origem e classificação dos solos afetados por sais. Editor(s): Gheyi, H. R., Dias, N. S., Lacerda, C. F. \& Filho E. G. In Manejo da Salinidade na Agricultura: Estudos Básicos e Aplicados. Fortaleza: INCT Sal, Pages 9-15.

Sá, F. V. S., Neto, M. F., de Lima, Y. B., Paiva, E. P., Prata, R. C., Lacerda, C. F. \& Brito, M. E. B. (2018). Growth, gas exchange and photochemical efficiency of the cowpea bean under salt stress and phosphorus fertilization. Comunicata Scientiae, 9(4), 668-679.

Sardinha, M., Müller, I.T., Schmeisky, H. \& Joergensen, R.G. (2003). Microbial performance in soils along a salinity gradient under acidic conditions. Applied Soil Ecology, 23, 237-244.

Shepherd, A.M. \& Clarke, A.J. (1971). Molting and hatching stimuli. In Zuckerrman, B.M., Mai, W.F. \& Rohde, R.A. Plant Parasitic Nematodes. London: Academic Press Inc., Pages 143-151.

Silva, L. D. R., Cartaxo, P. H. A., Silva, M. C., Gonzaga, K. S., Araújo, D. B., Sousa, E. S. \& Santos, J. P. O. (2020). Effect of rainfall variability on the production of Vigna unguiculata (L.) Walp. in the semi-arid region of Paraíba. Scientific Electronic Archives, 13(9), 26-32.

Silva, M. C. L., Santos, C. D. G. \& Silva, G. S. (2016). Espécies de Meloidogyne associadas a vegetais em microrregiões do estado do Ceará. Revista Ciência Agronômica, 47(4), 710-719.

Silva, M. D. C. L. \& Santos, C. D. G. (2017). Dispersão de Meloidogyne enterolobii em pomares de goiabeiras em municípios do estado do Ceará. Revista Caatinga, 30(2), 335-342.

Singh, A. (2021). Soil salinization management for sustainable development: A review. Journal of Environmental Management, $277,111383$.

Sobrinho, C. A. (2016). Principais Doenças do Feijão-Caupi no Brasil. In Bastos, E. A. A cultura do feijão-caupi no Brasil. Teresina: Embrapa Meio-Norte, Pages 44-66.

Souza, M. V. P., Sousa, G. G., Silva Sales, J. R., Costa Freire, M. H., Silva, G. L. \& Araújo Viana, T. V. (2019). Saline water and biofertilizer from bovine and goat manure in the Lima bean crop. Revista Brasileira de Ciências Agrárias, 14(3), 1-8.

Sumera, M. A., Saeed, R. \& Ahmed, T. (2015). Effect of salinity and root-knot nematode on growth of eggplant (Solanum melongena L.). FUUAST Journal of Biology, 5(1), 93-97.

Vasconcelos, R. R. A., Barros, M. F. C., Silva, E. F. F., Graciano, E. S. A., Fontenele, A. J. P. B. \& Silva, N. M. L. (2013). Características físicas de solos salino-sódicos do semiárido pernambucano em função de diferentes níveis de gesso. Revista Brasileira de Engenharia Agrícola e Ambiental, 17(12), 13181325 .

Wallace, H. R. (1966). Factors influencing the infectivity of plant parasitic nematodes. Proceedings of the Royal Society of London. Series B. Biological Sciences, 164(997), 592-614. 